\title{
Postprandial hyperlipidemia, endothelial dysfunction and cardiovascular risk: focus on incretins
}

\author{
Sameer Ansar ${ }^{1,3}$, Juraj Koska ${ }^{1}$ and Peter D Reaven ${ }^{1,2^{*}}$
}

\begin{abstract}
Cardiovascular disease (CVD) risk in type 2 diabetes (T2DM) is only partially reduced by intensive glycemic control. Diabetic dyslipidemia is suggested to be an additional important contributor to CVD risk in T2DM. Multiple lipid lowering medications effectively reduce fasting $L D L$ cholesterol and triglycerides concentrations and several of them routinely reduce CVD risk. However, in contemporary Western societies the vasculature is commonly exposed to prolonged postprandial hyperlipidemia. Metabolism of these postprandial carbohydrates and lipids yields multiple proatherogenic products. Even a transient increase in these factors may worsen vascular function and induces impaired endothelial dependent vasodilatation, a predictor of atherosclerosis and future cardiovascular events. There is a recent increased appreciation for the role of gut-derived incretin hormones in controlling the postprandial metabolic milieu. Incretin-based medications have been developed and are now used to control postprandial hyperglycemia in T2DM. Recent data indicate that these medications may also have profound effects on postprandial lipid metabolism and may favorably influence several cardiovascular functions. This review discusses (1) the postprandial state with special emphasis on postprandial lipid metabolism and its role in endothelial dysfunction and cardiovascular risk, (2) the ability of incretins to modulate postprandial hyperlipidemia and (3) the potential of incretin-based therapeutic strategies to improve vascular function and reduce CVD risk.
\end{abstract}

\section{Review}

\section{Cardiovascular risk in type 2 diabetes}

The prevalence of type 2 diabetes mellitus (T2DM) is increasing worldwide at alarming rates. In the next 20 years the prevalence of T2DM is expected to be more than 350 million people worldwide [1]. Cardiovascular disease (CVD) accounts for more than two thirds of all deaths in T2DM [2]. The risk of dying from CVD is nearly twice as high in those with T2DM compared with those of similar age without T2DM and this occurs similarly in both diabetic women and men $[3,4]$. Consistent with these effects on mortality, T2DM increases the risk of coronary and peripheral artery disease by 2 to 4 fold, while the risk of stroke is increased 10 fold in individuals younger than 55 years of age if they have T2DM [5-7].

\footnotetext{
* Correspondence: peter.reaven@va.gov

'Department of Endocrinology, Phoenix Veteran Affairs Healthcare System,

650 E Indian School Rd, CS111E, Phoenix, AZ 85012, USA

Full list of author information is available at the end of the article
}

Although the risk of major cardiovascular events in diabetes is closely related to glycemic control in observational studies, therapeutic targeting of glycated hemoglobin levels has not been effective in decreasing cardiovascular risk outcomes [8-12]. Furthermore, aggressive management of blood glucose levels per se does not substantially improve most cardiovascular risk factors commonly present in T2DM, including obesity, hypertension or diabetic dyslipidemia indicating that CVD risk management in T2DM requires more than improved glucose control. One of the potential explanations is that most diabetes medications show a neutral, and in some cases even harmful effect on some cardiovascular risk factors. Notably, these risk factors are already present at increased levels in individuals at high risk for T2DM and contribute to their increased cardiovascular risk [13-16].

\section{Postprandial lipids and cardiovascular risk}

Historically, the associations between metabolic abnormalities and cardiovascular disease have been

\section{C) Biomed Central}


studied largely during fasting conditions. However, the important contribution of postprandial state to cardiovascular disease is increasingly being recognized, particularly in conditions of insulin resistance and T2DM. The mechanisms of postprandial hyperglycemia, as well as its clinical importance (including cardiovascular) risk have been addressed in several excellent review articles [17-20] and we will instead focus on postprandial hyperlipidemia.

Multiple lipid lowering medications have been developed that effectively reduce fasting concentrations of LDL cholesterol and triglycerides (TG). Although several of these medications, particularly the statins, routinely reduce CVD risk by $25-35 \%$, there remains substantial residual and absolute risk in higher CVD risk populations, such as in T2DM. This may be in part explained by postprandial elevation in lipids. In fact, in contemporary post-industrialized societies most individuals spend the majority of non-sleeping hours in the postprandial state. For example, as the typical American diet consists of 3 or more meals per day and it takes more than 8 hours for triglyceride concentrations to return to fasting levels after a meal, postprandial triglyceride concentrations often remain elevated throughout the day. Importantly postprandial triglyceride concentrations may in fact be a better predictor of cardiovascular events than fasting triglycerides. The adverse effect of postprandial triglycerides is thought to be mediated by proatherogenic lipolysis products of nascent triglyceriderich lipoproteins, such as remnant lipoproteins and fatty acids, and even a transient increase in these factors may worsen vascular function.

Several large observational studies have assessed the association between non-fasting lipid concentrations and cardiovascular risk (Table 1). In the first of these, the association between non-fasting TG concentrations and risk of coronary death was assessed in 37,546 Norwegian male participants, aged 35-49 years, without a history of CVD and diabetes [21,22]. This analysis detected a weak, but statistically significant association between non-fasting TG and coronary death during an average of 9 years of follow-up [22]. When other coronary risk factors were adjusted for, non-fasting TG remained a significant independent predictor of coronary death only in participants within the upper age range, i.e. between 45 and 49 years, and with higher cholesterol levels [22]. In the subsequent analysis performed 4 years later in an even larger cohort of men and women, non-fasting TG were not associated with coronary death in men but showed a 5-fold risk of death from coronary heart disease in women with a non-fasting TG concentration of $3.5 \mathrm{mmol} / \mathrm{l}$ or more compared to those with a level of less than $1.5 \mathrm{mmol}$, even after adjustment for traditional coronary risk factors [21].
The Physicians' Health Study, a prospective nested case control study was conducted in 14,916 men aged 40 to 84 years, $85 \%$ of whom had baseline blood samples taken under non-fasting conditions [23]. The primary outcome was occurrence of myocardial infarction (MI) during 7 years of follow-up. A key finding was that cases $(n=266)$ had higher median non-fasting TG levels compared to controls $(\mathrm{n}=308)$. After simultaneous adjustment for age, smoking status, HDL- and total cholesterol levels, LDL diameter and a variety of coronary risk factors, non-fasting TG concentrations significantly predicted future risk of MI.

Non-fasting TG were also associated with myocardial infarction (MI) and ischemic heart disease and death after 26 years of follow-up in a prospective cohort of almost 14,000 women and men in the Copenhagen study [24]. The association was strongest among the individuals with higher categories of non-fasting triglyceride concentrations, but was weaker when TG levels were examined as a continuous variable and predicted MI in fully adjusted multivariate models only in women. In an additional analysis of this cohort, cumulative incidence of ischemic stroke was also directly proportional to the levels of the non-fasting TG [25].

Since none of the above studies included measurement of fasting lipids, it is not clear whether similar relationships with CVD would be observed with fasting TG values. However, the combination of a screening visit without requirements to be in fasting condition along with a protocol for strictly fasting enrollment visits in 2,809 asymptomatic men who participated in the Multiple Risk Factor Intervention Trial provided an opportunity to compare the effects of both fasting and non-fasting TG levels on non-fatal and fatal coronary heart disease [26]. The analyses showed a mild association of TG with CVD, which was similar for both fasting and non-fasting TG after 8 years of follow-up for both fatal as well as non-fatal coronary heart disease (CHD) events and after 25 years of observation for fatal CHD events [26]. A limitation of the study was that the time since the last meal prior to the non-fasting visit blood draw was not recorded.

In contrast, based on the time after the last meal for baseline blood draws, 26,509 initially healthy women in Women's Health Study [27] were stratified into fasting (8 and more hours since last meal) and non-fasting groups (meal within 8 hours prior to blood collection). After adjustment for standard cardiovascular risk factors including total and HDL cholesterol, diabetes status, body mass index (BMI) and C-reactive protein (CRP), fasting TG levels were not associated with incident cardiovascular events over an 11-year follow-up period. On the other hand, non-fasting triglycerides maintained a strong independent relationship with future cardiovascular events 
Table 1 Relative risk of cardiovascular outcomes with non-fasting triglyceride levels

\begin{tabular}{|c|c|c|c|c|}
\hline Author (year) & Population & $\begin{array}{l}\text { Follow- } \\
\text { up }\end{array}$ & Outcome(s) (number of events) & $\begin{array}{l}\text { Adjusted relative } \\
\text { risk }(95 \% \mathrm{Cl})\end{array}$ \\
\hline $\begin{array}{l}\text { Tverdal et al. } \\
\text { (1989) [22] }\end{array}$ & $\begin{array}{l}37,546 \text { men aged } 35-49 \text { years, without history of } \\
\text { CVD or diabetes }\end{array}$ & $\begin{array}{l}9 \text { years } \\
\text { (mean) }\end{array}$ & coronary death $(n=369)$ & $1.1(1.0-1.2)$ \\
\hline $\begin{array}{l}\text { Stensvold et al. } \\
\text { (1993) [21] }\end{array}$ & $\begin{array}{l}24,535 \text { women, aged } 35-49 \text { years, without history } \\
\text { of CVD or diabetes }\end{array}$ & $\begin{array}{l}14.6 \text { years } \\
\text { (mean) }\end{array}$ & coronary death $(n=108)$ & $\begin{array}{l}\text { men: } 1.1(1.0-1.2) \\
\text { women: } 1.6(1.2-2.1)\end{array}$ \\
\hline $\begin{array}{l}\text { Stampfer et al. } \\
\text { (1996) [23] }\end{array}$ & $\begin{array}{l}14,916 \text { men without history of CVD ( } 85 \% \text { non- } \\
\text { fasting) }\end{array}$ & 7 years & $\begin{array}{l}\text { myocardial infarction, cases }(n=266) \text { vs. } \\
\text { controls }(n=308)\end{array}$ & $1.4(1.1-1.8)$ \\
\hline $\begin{array}{l}\text { Eberly et al. } \\
\text { (2003) [26] }\end{array}$ & $\begin{array}{l}\text { 2,809 male participants without clinical evidence of } \\
\text { CVD in the MRFIT study }\end{array}$ & 25 years & $\begin{array}{l}\text { 8-year non-fatal or fatal CHD }(n=175) \\
25 \text {-year fatal CHD }(n=328)\end{array}$ & $\begin{array}{l}1.6(1.2-2.3) \text { fasting } \\
1.5(1.0-2.1) \text { non- } \\
\text { fasting } \\
1.2(1.0-1.6) \text { fasting } \\
1.3(1.0-1.6) \text { non- } \\
\text { fasting }\end{array}$ \\
\hline $\begin{array}{l}\text { Nordestgaard et } \\
\text { al. (2007) [24] }\end{array}$ & $\begin{array}{l}\text { 7,587 women and 6,394 men form the general } \\
\text { population in Copenhagen (Denmark) }\end{array}$ & $\begin{array}{l}26 \text { years } \\
\text { (mean) }\end{array}$ & $\begin{array}{l}\text { myocardial infarction }(n=1,793) \\
\text { ischemic heart disease }(n=3,479)\end{array}$ & $\begin{array}{l}1.2(1.1-1.4) \text { women } \\
1.0(1.0-1.1) \text { men } \\
1.1(1.0-1.2) \text { women } \\
1.0(1.0-1.1) \text { men }\end{array}$ \\
\hline $\begin{array}{l}\text { Bansal et al. } \\
(2007)[27]\end{array}$ & $\begin{array}{l}\text { 26,509 healthy US women, 20,118 fasting, 6,391 } \\
\text { non-fasting ( }<8 \text { hours since last meal) }\end{array}$ & $\begin{array}{l}11.4 \text { years } \\
\text { (mean) }\end{array}$ & cardiovascular events $(n=1001)$ & $\begin{array}{l}1.1(0.9-1.3) \text { fasting } \\
1.7(1.2-2.4) \text { non- } \\
\text { fasting } \\
4.5(2.0-10.2) 2-4 \text { hrs } \\
\text { since last meal }\end{array}$ \\
\hline
\end{tabular}

even in the fully adjusted analyses. Moreover, after stratification by time since the last meal, TG concentrations measured 2-4 hours after the last meal were the strongest predictor of CVD events.

\section{Postprandial lipid metabolism and vascular risk}

Triglycerides of dietary origin enter the lymph and then systemic circulation as chylomicrons packaged together with apolipoprotein B-48 (apoB-48). Following a fat enriched meal, chylomicrons rapidly increase and lead to pronounced triglyceride elevations peaking approximately 4 hours post-meal. In humans, the presence of apoB-48 distinguishes chylomicrons from smaller VLDL particles carrying triglycerides of hepatic origin that contain apolipoprotein B-100 (apoB-100). Although increases in particles carrying apoB-48 explain about $80 \%$ of the postprandial triglyceride increase, much of the increase in the particle count is represented by particles containing apoB-100 [28]. Both chylomicrons and VLDL lipoproteins are cleared from the circulation after undergoing lipolysis by several lipases, i.e. lipoprotein or hepatic lipases, producing fatty acids and smaller remnant lipoprotein particles (RLP). Since these enzyme pathways have limited capacity, there is competition in clearance between both VLDL and chylomicrons [28]. One important consequence of chylomicrons lipolysis is that it reduces the size of lipoproteins sufficiently to permit entry into the arterial wall, where proatherogenic properties of these modified lipoproteins (described below) may alter vascular function.

RLPs after lipolysis become enriched in cholesterol, deposit 5- to 20-fold more cholesterol into the vessel wall per particle, and are preferentially retained in the vessel wall where they are avidly taken up by macrophages [29-31]. RLPs have been shown to be proinflammatory causing endothelial dysfunction, and induction of monocytes chemoattracting protein 1 (MCP-1) expression by vascular smooth muscle cells [32,33]. Consistent with this, increased RLPs have also been associated with coronary artery disease, and predict progression of atherosclerosis and development of cardiovascular events [34-36]. Postprandial changes in RLPs closely correlate with postprandial changes in TG [37]. Apolipoprotein CIII (apoCIII) appears to be an important inhibitor of RLPs clearance [38,39]. Furthermore, recent in vitro and in vivo experimental data showed that apoCIII may directly induce endothelial dysfunction via inhibition of insulin-induced activation of Akt resulting in reduced nitric oxide (NO) release and subsequent impaired vasodilation [40]. Possibly as a consequence, high levels of apoCIII in plasma, or in VLDL particles, are associated with increased risk of CVD $[39,41]$.

Fatty acids, an additional product of postprandial TG hydrolysis, may also contribute to increased cardiovascular risk. Increased non-esterified fatty acids (NEFA) concentrations are prospectively associated with both cardiovascular morbidity and mortality $[42,43]$. NEFA effects on the cardiovascular system include injury to both the myocardium and increased susceptibility to arrhythmias [44], and to the vasculature, by stimulation of inflammatory processes, local production of reactive oxygen species and impaired endothelial dependent vasodilation [45-47]. Fatty acids could further facilitate 
development of atherosclerotic plaque through stimulation of inflammatory processes in macrophages [48].

\section{The postprandial state and endothelial dysfunction}

Endothelial dysfunction is believed an important link between the postprandial state, atherosclerosis and CVD. It is characterized by impaired endotheliumdependent vasodilation and increased pro-coagulant and pro-inflammatory activity [49]. Coronary endothelial dysfunction has been shown to predict cardiovascular events in patients with and without coronary artery disease [50-52]. Although coronary endothelial dysfunction is commonly present in individuals with a long history of T2DM, it is also present in those with insulin resistance, prediabetes and/or new onset T2DM [53,54]. Studies have demonstrated that endothelial function in both healthy subjects and those with T2DM is altered by meals with high amounts of fat or carbohydrates $[55,56]$ and is inversely related to both glucose and TG concentrations [56-58]. Since endothelial dysfunction is a diffuse process, measurement of endothelial function in peripheral arteries can be used as a surrogate of coronary endothelial function. Peripheral endothelial function correlates well with coronary endothelial vasodilation and is reduced in patients with cardiovascular risk factors such as obesity, hypercholesterolemia, hypertension and diabetes [54,59-62]. Lower peripheral endothelial function also predicts progression of carotid atherosclerosis in the general population as well as cardiovascular morbidity and mortality in populations with high CVD risk [63-68].

\section{Endogenous incretin hormones in regulation of glucose, lipid and vascular responses}

The incretin hormones, glucagon-like peptide-1 (GLP-1) produced by L-cells in the distal gut, and glucosedependent insulinotropic polypeptide (GIP) produced by duodenal $\mathrm{K}$-cells in response to ingested nutrients, are important regulators of glucose homeostasis [69]. Incretins are secreted into the circulation within minutes in response to a meal and upon release they bind to specific G-protein coupled receptors present on $\beta$-cells and other target tissues [70,71]. GLP-1 is secreted in greater concentrations than GIP and is considered more physiologically relevant in humans [72]. In $\beta$-cells, GLP-1 enhances glucose-dependent insulin secretion, increases insulin synthesis, and in animals stimulates $\beta$-cell proliferation and inhibits apoptosis [69]. GLP-1 also reduces glucose concentrations through inhibition of pancreatic $\alpha$-cell glucagon secretion and indirectly via inhibition of gastric emptying and appetite [73-75]. Importantly, in addition to slowing gastric emptying, GLP-1 may also decrease intestinal lymph flow, triglyceride absorption, and apolipoprotein synthesis adding to a complex combination of mechanisms that may limit the release of triglycerides into the circulation after lipid-containing meals [76] (Figure 1). Consistent with this, administration of GLP-1 or GLP-1 receptor agonists in humans is associated with significant reduction of postprandial lipids (Table 2). Intravenous infusion of GLP-1 abolished the rise in postprandial triglyceride concentrations in healthy men [77]. Furthermore, it also decreased fasting and postprandial NEFA concentrations [77] in agreement with a previous report on the effect of 6 week continuous subcutaneous GLP-1 infusion in patients with T2DM [78] (Table 2).

Notably, the incretin effect appears reduced or lost in individuals with impaired glucose tolerance and T2DM $[79,80]$. This is most commonly ascribed to reduced endogenous levels of GLP-1. However, as GLP-1 receptor signaling remains intact, continuous administration of GLP-1 effectively reduces blood glucose levels in patients with T2DM $[81,82]$.

Recent studies indicate that GLP-1 may also exert beneficial effects on the cardiovascular system independent of its effects on glucose, lipid or energy metabolism [83]. In vitro, the active form of GLP-1 (7-36) induced endothelium-dependent vasodilation in preconstricted pulmonary arteries [84]. In vitro, GLP-1 inhibited tumor necrosis factor alpha (TNF- $\alpha$ ) induced plasminogen activator inhibitor 1 (PAI-1) gene and protein expression in endothelial cells [85]. In vivo, administration of GLP-1 improved endothelial function in salt-sensitive hypertensive rats [86]. Of great relevance, pharmacological levels of GLP-1 improved endothelial function in healthy individuals as well as in T2DM patients with stable coronary artery disease $[87,88]$ and had a protective effect on postprandial endothelial function [89]. In addition to these vascular effects, GLP-1 or GLP-1 receptor agonists demonstrated multiple beneficial actions on the heart including protection of myocardium from ischemia in rats [90], improvement of cardiac function in rats with congestive heart failure [91] and attenuation of ischemic left ventricular dysfunction during stress echocardiography in patients with coronary artery disease [92].

\section{Incretin-based therapies to reduce postprandial dyslipidemia and improve endothelial dysfunction}

Although GLP-1 is highly effective in lowering blood glucose and has promising cardiovascular effects, its therapeutic potential is severely limited because of rapid degradation by dipeptidyl peptidase 4 (DPP-4) to GLP-1 (9-36) which does not stimulate GLP-1 receptor and therefore does not exert the metabolic effects of active GLP-1 [93]. Therefore, the therapeutic focus has been directed towards compounds that either mimic the activities of GLP-1 while being less susceptible to 


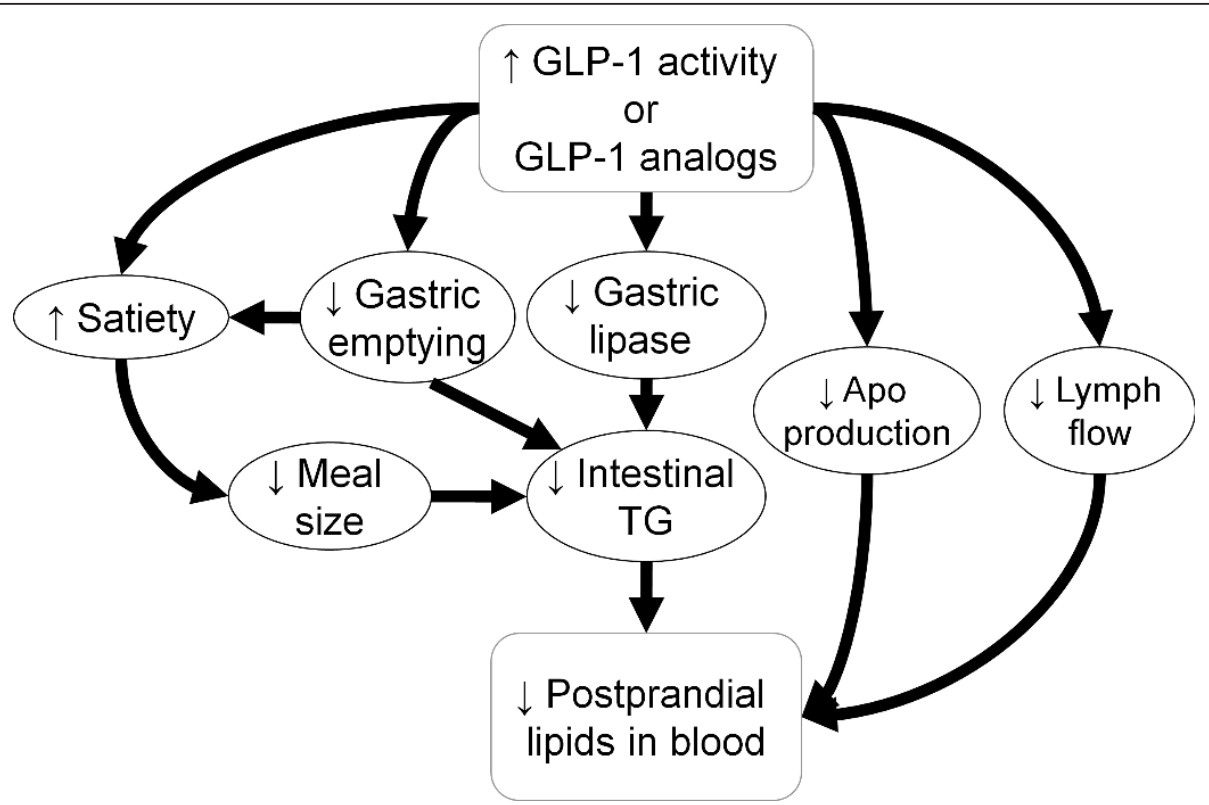

Figure 1 A scheme of the complex effect of incretin activity on postprandial lipids. GLP-1 or GLP-1 receptor agonists acting on the central nervous system increases satiety and therefore reduces nutrient intake. Inhibitory GLP-1 activity on gastric emptying both further increases satiety and slows entry of nutrients including lipids into the intestine. Triglyceride (TG) absorption into intestinal cells is further reduced because of incretin-induced inhibition of gastric lipase. In the intestinal cells, incretins also decrease production of apolipoproteins (Apo) B-48 and A-IV thereby inhibiting intestinal biosynthesis of triglycerides and their secretion into blood. Transport of lipids from intestinal cells to blood may be further reduced by inhibitory effect of incretins on intestinal lymph flow. This combination of effects leads to lowering of postprandial lipid levels in blood.

Table 2 The effect of incretins or incretin based therapies on postprandial lipid metabolism in humans

\begin{tabular}{|c|c|c|c|c|c|}
\hline Compound & Author & Intervention & Design & Study population & Findings \\
\hline GLP-1 & $\begin{array}{l}\text { Meier et al. } \\
\text { (2006) [77] }\end{array}$ & 390-min IV infusion & $\begin{array}{l}\text { randomized, double } \\
\text { blinded, placebo- } \\
\text { controlled crossover } \\
\text { study }\end{array}$ & $\begin{array}{l}14 \text { healthy male } \\
\text { volunteers }\end{array}$ & $\begin{array}{c}\text { Reduced postprandial triglyceride and } \\
\text { NEFA levels }\end{array}$ \\
\hline$\overline{\mathrm{GLP}-1}$ & $\begin{array}{l}\text { Zander } \\
\text { et al. } \\
(2002)[78]\end{array}$ & $\begin{array}{l}\text { 6-week continuous SQ } \\
\text { infusion }\end{array}$ & $\begin{array}{l}\text { randomized, single- } \\
\text { blinded, placebo } \\
\text { controlled parallel study }\end{array}$ & $\begin{array}{l}20 \text { patients with T2DM } \\
\text { (10 in each group) }\end{array}$ & $\begin{array}{c}\text { Decreased fasting and average 8-h post- } \\
\text { meal NEFA levels }\end{array}$ \\
\hline Exenatide & $\begin{array}{l}\text { Cervera } \\
\text { et al. } \\
(2008)[98]\end{array}$ & $\begin{array}{l}\text { 6-hour continuous IV } \\
\text { infusion }\end{array}$ & $\begin{array}{l}\text { non-randomized single- } \\
\text { blinded crossover study } \\
\text { vs. control }\end{array}$ & 12 subjects with T2DM & $\begin{array}{c}\text { Reduced triglyceride response to mixed } \\
\text { meal }\end{array}$ \\
\hline Exenatide & $\begin{array}{l}\text { Schwartz } \\
\text { et al. } \\
\text { (2008) [99] }\end{array}$ & $\begin{array}{c}\text { 2-week SQ injection twice } \\
\text { a day }\end{array}$ & $\begin{array}{l}\text { randomized, double- } \\
\text { blinded, placebo- } \\
\text { controlled parallel study }\end{array}$ & $\begin{array}{c}30 \text { patients with } \\
\text { inadequately controlled } \\
\text { T2DM }\end{array}$ & $\begin{array}{l}\text { Decreased morning and evening } \\
\text { postprandial triglyceride excursions, no } \\
\text { effect after midday meal }\end{array}$ \\
\hline Exenatide & $\begin{array}{l}\text { Schwartz } \\
\text { et al. } \\
\text { (2010) } \\
{[103]}\end{array}$ & $\begin{array}{c}\text { Single SQ dose just before } \\
\text { a high-fat meal }\end{array}$ & $\begin{array}{c}\text { randomized, double- } \\
\text { blinded, placebo- } \\
\text { controlled crossover } \\
\text { study }\end{array}$ & $\begin{array}{c}35 \text { patients with } \\
\text { impaired glucose } \\
\text { tolerance or recent } \\
\text { T2DM }\end{array}$ & $\begin{array}{l}\text { Abolished responses of triglyceride, } \\
\text { NEFA, RLPs, apoB48 and apoCIII to meal }\end{array}$ \\
\hline $\begin{array}{l}\text { Exenatide } \\
\text { or } \\
\text { Sitagliptin }\end{array}$ & $\begin{array}{l}\text { DeFronzo } \\
\text { et al. } \\
\text { (2008) } \\
{[100]}\end{array}$ & $\begin{array}{l}\text { 2-week SQ exenatide } \\
\text { injection twice a day or } \\
\text { sitagliptin orally once/day }\end{array}$ & $\begin{array}{l}\text { double-blinded } \\
\text { randomized crossover } \\
\text { study }\end{array}$ & $\begin{array}{l}61 \text { patients with T2DM } \\
\text { treated with a stable } \\
\text { regimen metformin }\end{array}$ & $\begin{array}{c}\text { Reduced average } 4 \text {-h post-meal } \\
\text { triglyceride response after both. } \\
\text { Reduction greater after exenatide (by } \\
\sim 10 \%)\end{array}$ \\
\hline Vildagliptin & $\begin{array}{l}\text { Matikainen } \\
\text { et al. } \\
\text { (2006) } \\
{[107]}\end{array}$ & $\begin{array}{l}\text { 4-week oral dose } 50 \mathrm{mg} \\
\text { twice/day }\end{array}$ & $\begin{array}{c}\text { double-blinded } \\
\text { randomized placebo- } \\
\text { controlled parallel study }\end{array}$ & $\begin{array}{l}31 \text { drug-naive T2DM } \\
\text { patients ( } n=16 \\
\text { allocated to Vildagliptin) }\end{array}$ & $\begin{array}{c}\text { Decreased postprandial TG-rich } \\
\text { lipoproteins (total and chylomicrons, } \\
\text { apoB-48) }\end{array}$ \\
\hline
\end{tabular}


degradation by DPP-4 or that reduce degradation of endogenous GLP-1 (and GIP) by inhibiting DPP-4. However, the effect of these therapies on CVD is unknown.

Exenatide (exendin-4), the first FDA approved GLP-1 mimetic, has only $53 \%$ homology to the human GLP-1 amino acid sequence; as such, it is relatively more resistant to DPP-4, reaching maximum levels approximately 2 hours following subcutaneous injection [94]. Exenatide reproduces many of the action of GLP-1, such as enhancement of glucose-induced insulin secretion, inhibition of glucagon release, reduction of fasting and postprandial glucose concentrations, delay of gastric emptying, inhibition of appetite and induction of weight loss [94-97]. Acute infusion or short-term treatment with exenatide twice a day abolished increments in postprandial triglyceride concentrations in patients with T2DM [98-100] (Table 2). Long-term treatment with exenatide was associated with significant improvement in multiple cardiovascular risk factors including systolic and diastolic blood pressure, fasting triglycerides, as well as total, LDL- and HDL-cholesterol [101]. Recent experimental data indicate anti-atherosclerotic effects of exenatide involving inhibition of inflammatory responses of atherosclerotic plaque macrophages [102].

To assess the effects of typical clinical dosing of exenatide on postprandial lipid and lipoprotein excursions, we conducted a double-blinded, randomized, placebocontrolled, crossover study in participants with IGT or with recent onset T2DM in good control with diet alone [103]. The intervention was a single subcutaneous injection of exenatide $(10 \mu \mathrm{g})$ or normal saline just prior to a high-caloric $\left(600 \mathrm{kcal} / \mathrm{m}^{2}\right)$, fat-enriched breakfast meal (45\% fat, $40 \%$ carbohydrates, $15 \%$ proteins). Blood was collected for lipid assays over an 8 hour postprandial period. The single dose of exenatide strongly suppressed postprandial elevation of TG, apoB-48, RLP-TG and RLP-cholesterol (Figure 2) as well as apoCIII, whereas
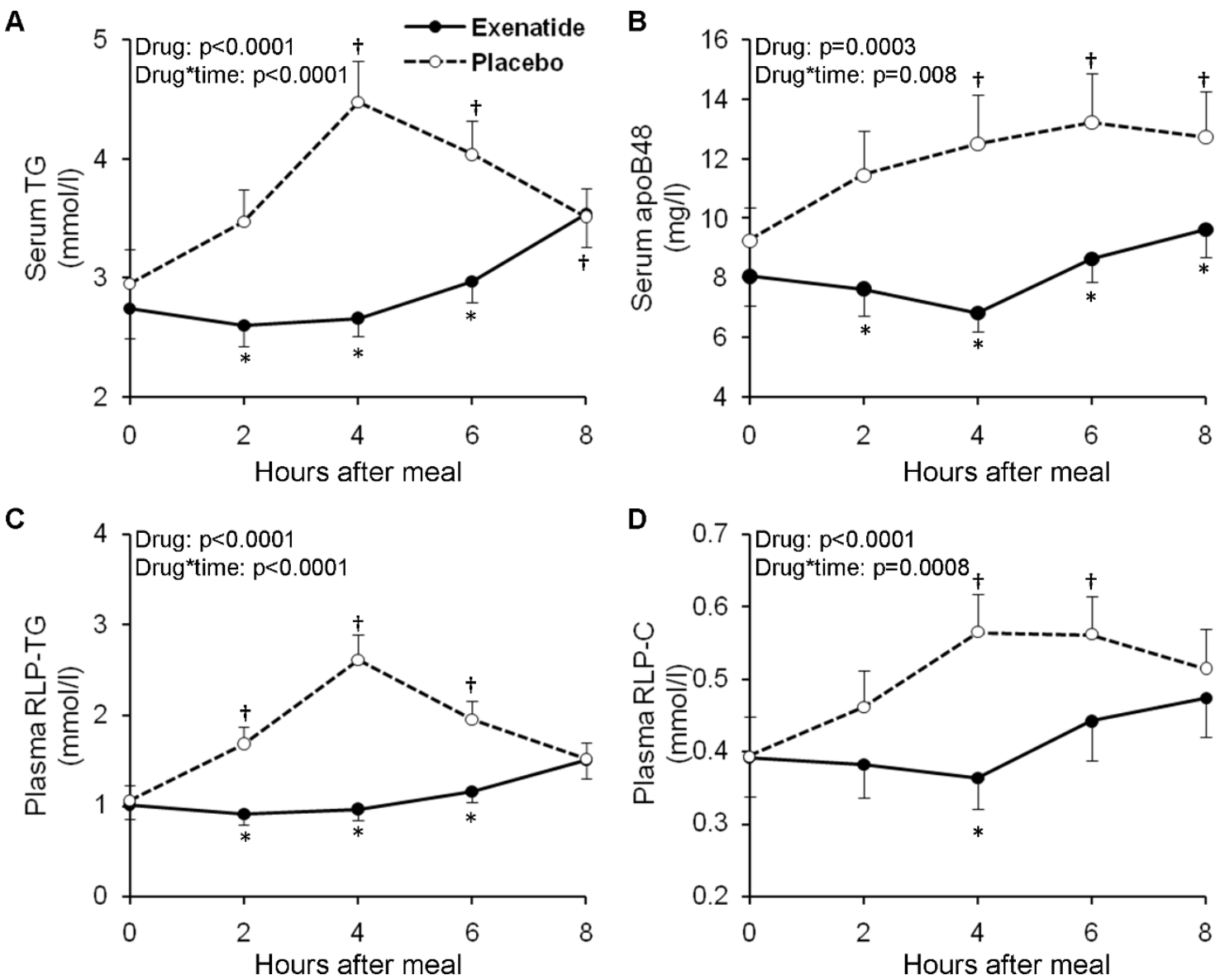

Figure 2 The effect of exenatide or placebo on postprandial concentrations of triglycerides (panel A) and apolipoprotein B-48 (apoB48, panel B) in serum, and remnant lipoprotein triglycerides (RLP-TG, panel C) and cholesterol (RLP-C, panel D) in plasma. The average effect of study medication (Drug) and the interaction between the effects of meal and drug (Drug*Time) were evaluated by repeated measures ANCOVA (adjusted for test sequence and glucose tolerance status). Symbols denote statistically significant $(p<0.05)$ difference between exenatide and placebo $(\ddagger)$ and versus pre-meal value $\left(^{*}\right)$ at each specified time points tested by post-hoc multiple comparison analyses Number of subjects included in the analyses: triglycerides, $n=35 ; \mathrm{RLP}-\mathrm{TG}, \mathrm{n}=34 ; \mathrm{RLP}-\mathrm{C}, \mathrm{n}=31$; apoB48, $\mathrm{n}=28$ (Schwartz et al., Atherosclerosis 2010, 212(1):217-222 [103]) 
declines in NEFA were less pronounced but persisted longer in exenatide compared with placebo (Table 2). These effects of exenatide were similar in those with IGT or recent onset T2DM demonstrating that exenatide profoundly inhibits postprandial excursions of proatherogenic lipids and lipoproteins and may reduce cardiovascular risk in those early in the evolution of diabetes. These lipid and lipoprotein lowering effects of exenatide were present regardless of concomitant therapy of dyslipidemia with statins.

We also tested whether the metabolic effects of exenatide would translate to improved postprandial endothelial dysfunction [104]. Twenty eight of the study participants successfully completed both pre- and postmeal measurement of peripheral endothelial function using finger plethysmography (peripheral arterial tonometry - PAT). A single exenatide administration was followed by significant improvement of postprandial endothelial function compared to the placebo treatment (Figure 3). Two thirds of exenatide's effect was explained by changes in triglyceride concentrations indicating that modulation of postprandial lipid metabolism played a major role in observed improvement of endothelial function. In agreement with previous reports of postprandial endothelial dysfunction in individuals with T2DM [56], our data also reinforced increased susceptibility of diabetic individuals to postprandial impairment of endothelial function. Furthermore, they suggested that this susceptibility develops very early after onset of T2DM as it was absent in persons with IGT and present in the recently diagnosed T2DM

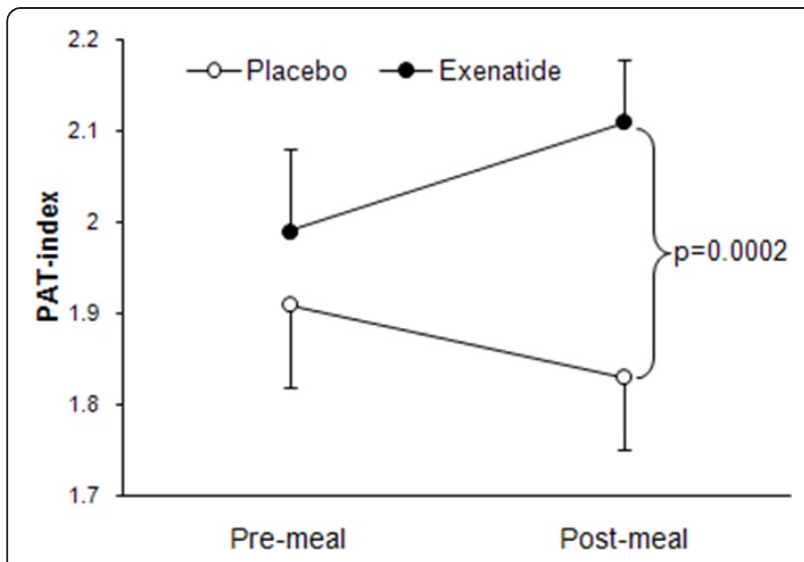

Figure 3 The effects of exenatide and placebo on postprandial endothelial function. Endothelial function was measured before and after a single high-fat breakfast meal. Participants received placebo and exenatide on separate visits in a cross-over design. Post-meal PAT index was significantly higher (demonstrating improved endothelial function) during the exenatide phase compared with the placebo phase ( $p=0.0002$, adjusted for premeal PAT index, treatment sequence and glucose tolerance status) (Koska et al., Diabetes Care 2010, 33(5):1028-1030 [104]). subjects with good glycemic control. Importantly, the benefit of exenatide on postprandial endothelial function was similar among those with IGT and diabetes, i.e. it prevented the postprandial decrease of endothelial function in T2DM and induced an increase in endothelial vasodilation of similar magnitude in IGT, demonstrating that exenatide therapy beneficially influences endothelial function in both prediabetes and early stages of T2DM.

Clinical studies with DPP-4 inhibitors provide additional support for incretin-based therapies as an effective tool in ameliorating postprandial dyslipidemia. These compounds only moderately increase endogenous GLP1 levels and as such they do not have a detectable effect on gastric emptying rate $[105,106]$. Despite this, the ability of the DPP-4 inhibitor sitagliptin to reduce postprandial TG levels was only about $10 \%$ less than exenatide in a two-week cross-over study in patients with T2DM [100] (Table 2). In a separate double-blinded placebocontrolled study in drug-naïve T2DM patients, Matikainen et al. [107] demonstrated that 4-weeks therapy with another DPP-4 inhibitor, vildagliptin, also decreased postprandial TG levels (Table 2). They also demonstrated that the reduction in triglycerides was accounted for by reduced TG in chylomicrons and lower apoB-48. In contrast, there were not significant changes in VLDL TG or apoB-100 levels [107]. A direct inhibitory effect of incretins on intestinal lipid secretion is further supported by data showing that intestinal production of apoB-48 both in vitro and in vivo in rodents was profoundly reduced by both exendin-4 and sitagliptin [108]. A summary of these incretin-mediated mechanisms contributing to lowering of postprandial lipids is illustrated in Figure 1.

\section{Prospects for incretin-based therapies to reduce cardiovascular risk}

Since more intensive glycemic control with standard diabetes medications has been largely ineffective in reducing the high residual cardiovascular risk in individuals with T2DM, aggressive treatment of other cardiovascular risk factors appears to be the logical next step in the effort to decrease cardiovascular risk in this group. In fact, the results of the STENO-2 study show that a target-driven, long-term, intensified intervention aimed at multiple risk factors in patients with type 2 diabetes and microalbuminuria, may reduce the risk of cardiovascular events by about 50 percent [109]. An increasing body of clinical evidence indicates that incretin-based therapies not only lower fasting and postprandial glucose, but also improve a wide variety of traditional cardiovascular risk factors including obesity, high blood pressure as well as fasting and postprandial lipid and apolipoprotein concentrations [99-101,107,110-113]. Importantly, the effect of incretins on postprandial lipid excursions appears acute and 
Table 3 Recently launched multi-center, randomized, placebo controlled longitudinal studies evaluating cardiovascular benefit of incretin-based therapies in individuals with type 2 diabetes (Source: http://www.clinicaltrials.gov)

\begin{tabular}{lllllcc}
\hline Trial & Active drug & Category & Phase & N & Start & Duration \\
\hline EXSCEL & Exenatide QW (weekly) & GLP-1 agonist & III & 9,500 & June 2010 & $63 / 4$ years \\
\hline LEADER & Liraglutide & GLP-1 agonist & IV & 8,754 & August 2010 & $61 / 4$ years \\
\hline TECOS & Sitagliptin & DPP-IV inhibitor & IV & 14,000 & December 2008 & 6 years \\
\hline SAVOR-TIMI53 & Saxagliptin & DPP-IV inhibitor & IV & 12,000 & May 2010 & 5 years \\
\hline
\end{tabular}

therefore may be additive to lipid benefits of decreased appetite and body weight reduction that are characteristic of more chronic therapy with incretins or incretin analogues [77,98,103]. Moreover, some experimental data in humans show that increased GLP-1 activity may directly stimulate endothelial-mediated vasodilation independently of known metabolic actions of GLP-1 [87,88,104]. Exendin4 also attenuated atherosclerotic lesions in mice model of atherosclerosis [102]. The attenuation was associated with reduced monocyte/macrophage accumulation in the arterial wall indicating that suppression of vascular inflammation may represent another direct cardiovascular benefit of incretin-based therapy [102].

\section{Conclusions}

Although this review highlights clinical and experimental data that provide evidence for favorable cardiovascular effects of incretins, the lack of outcome studies and the short history of clinical use of these agents limit our knowledge about their clinical cardiovascular efficacy. Large multi-center longitudinal studies designed not just to prove CVD safety as shown in two recent meta-analyses of short-term randomized clinical trials of exenatide [114] or sitagliptin [115], but to demonstrate cardiovascular benefits of incretin-based strategies, appear warranted and have recently been initiated (Table 3). In support of this goal, post-hoc analyses within the ACCORD cohort indicated that the only diabetes medication associated with a decrease in CVD events was exenatide [116]. Furthermore, a retrospective study using LifeLinkTM database of medical and pharmaceutical insurance claims for June, 2005 through March, 2009 found that 39,275 patients with type 2 diabetes were treated with exenatide twice daily were less likely to have a CVD event, lower rates of CVD-related and all-cause hospitalization compared to 381,218 patients treated with other glucose-lowering therapies [117]. Moreover, mathematical models accounting for the constellation of CVD risk factors affected by incretin analogs (exenatide in this specific case) predict greater reductions in major adverse cardiovascular events than glucose-lowering regimens without incretins [118]. However, the results of ongoing studies will clarify whether incretin-based therapies live up to their promise as vasculoprotective agents.

\section{List of abbreviations}

apoB-100: apolipoprotein B-100; apoB-48: apolipoprotein B-48; apoCII: apolipoprotein CIII; BMI: body mass index; CHD: coronary heart disease; CVD: cardiovascular disease; CRP: C-reactive protein; DPP-4: dipeptidyl peptidase 4; GIP: glucose-dependent insulinotropic polypeptide; GLP-1: glucagon-like peptide-1; IGT: impaired glucose tolerance; MCP-1: monocytes

chemoattracting protein 1; Ml: myocardial infarction; NEFA: non-esterified fatty acids; NO: nitric oxide; PAl-1: plasminogen activator inhibitor 1; PAT: peripheral arterial tonometry; RLPS: remnant lipoprotein particles; T2DM: type 2 diabetes mellitus; TNF-a: tumor necrosis factor alpha.

\section{Acknowledgements}

This work was supported in part by the office of Research and Development, Medical Research Service, Department of Veterans Affairs. The contents of this article do not represent the views of the Department of Veterans Affairs or The United States Government.

\section{Author details}

'Department of Endocrinology, Phoenix Veteran Affairs Healthcare System, 650 E Indian School Rd, CS111E, Phoenix, AZ 85012, USA. 'Biodesign Institute, Arizona State University, 727 E. Tyler Street Tempe, AZ 85287, USA. ${ }^{3}$ Michigan State University, B319 Clinical Center, East Lansing, MI 48824, USA.

\section{Authors' contributions}

SA and JK drafted the manuscript. PDR conceived of the concept, initiated and helped drafting, and reviewed the final version of the manuscript. All authors read and approved the final manuscript.

\section{Competing interests}

JK and PDR are recipients of unrestricted research grants from Amylin/Lilly SA declares no competing interests.

Received: 6 May 2011 Accepted: 7 July 2011 Published: 7 July 2011

\section{References}

1. Yach D, Stuckler D, Brownell KD: Epidemiologic and economic consequences of the global epidemics of obesity and diabetes. Nat Med 2006, 12(1):62-66.

2. Haffner SM, Lehto S, Ronnemaa T, Pyorala K, Laakso M: Mortality from coronary heart disease in subjects with type 2 diabetes and in nondiabetic subjects with and without prior myocardial infarction. $N$ Engl J Med 1998, 339(4):229-234.

3. Kannel WB, McGee DL: Diabetes and cardiovascular disease. The Framingham study. JAMA 1979, 241(19):2035-2038.

4. Pan WH, Cedres LB, Liu K, Dyer A, Schoenberger JA, Shekelle RB, Stamler R, Smith D, Collette P, Stamler J: Relationship of clinical diabetes and asymptomatic hyperglycemia to risk of coronary heart disease mortality in men and women. Am J Epidemiol 1986, 123(3):504-516.

5. Feskens EJ, Kromhout D: Glucose tolerance and the risk of cardiovascular disease: the Zutphen Study. J Clin Epidemiol 1992, 45(11):1327-1334.

6. Newman JM, DeStefano F, Valway SE, German RR, Muneta B: Diabetesassociated mortality in Native Americans. Diabetes Care 1993, 16(1):297-299. 
7. You RX, McNeil JJ, O'Malley HM, Davis SM, Thrift AG, Donnan GA: Risk factors for stroke due to cerebral infarction in young adults. Stroke 1997, 28(10):1913-1918.

8. Moss SE, Klein R, Klein BEK: Risk Factors for Hospitalization in People With Diabetes. Arch Intern Med 1999, 159(17):2053-2057.

9. Selvin E, Marinopoulos S, Berkenblit G, Rami T, Brancati FL, Powe NR, Golden SH: Meta-analysis: glycosylated hemoglobin and cardiovascular disease in diabetes mellitus. Ann Intern Med 2004, 141(6):421-431.

10. Duckworth W, Abraira C, Moritz T, Reda D, Emanuele N, Reaven PD, Zieve FJ, Marks J, Davis SN, Hayward R, et al: Glucose Control and Vascular Complications in Veterans with Type 2 Diabetes. N Engl J Med 2009, 360(2):129-139.

11. The ACG: Intensive Blood Glucose Control and Vascular Outcomes in Patients with Type 2 Diabetes. N Engl J Med 2008, 358(24):2560-2572.

12. The Action to Control Cardiovascular Risk in Diabetes Study G: Effects of Intensive Glucose Lowering in Type 2 Diabetes. N Engl J Med 2008, 358(24):2545-2559.

13. D'Agostino RB Jr, Hamman RF, Karter AJ, Mykkanen L, Wagenknecht LE, Haffner SM: Cardiovascular disease risk factors predict the development of type 2 diabetes: the insulin resistance atherosclerosis study. Diabetes Care 2004, 27(9):2234-2240.

14. Feskens EJ, Kromhout D: Cardiovascular risk factors and the 25 -year incidence of diabetes mellitus in middle-aged men. The Zutphen Study. Am J Epidemiol 1989, 130(6):1101-1108.

15. Haffner SM, Stern MP, Hazuda HP, Mitchell BD, Patterson JK: Cardiovascular risk factors in confirmed prediabetic individuals. Does the clock for coronary heart disease start ticking before the onset of clinical diabetes? JAMA 1990, 263(21):2893-2898.

16. Hu FB, Stampfer MJ, Haffner SM, Solomon CG, Willett WC, Manson JE: Elevated risk of cardiovascular disease prior to clinical diagnosis of type 2 diabetes. Diabetes Care 2002, 25(7):1129-1134.

17. Bianchi C, Miccoli R, Penno G, Del Prato S: Primary Prevention of Cardiovascular Disease in People With Dysglycemia. Diabetes Care 2008, 31(Supplement 2):S208-S214.

18. Fava S: Role of postprandial hyperglycemia in cardiovascular disease. Expert Review of Cardiovascular Therapy 2008, 6(6):859-872.

19. Gerich JE: Clinical Significance, Pathogenesis, and Management of Postprandial Hyperglycemia. Arch Intern Med 2003, 163(11):1306-1316.

20. Milicevic Z, Raz I, Beattie SD, Campaigne BN, Sarwat S, Gromniak E, Kowalska I, Galic E, Tan M, Hanefeld M: Natural History of Cardiovascular Disease in Patients With Diabetes. Diabetes Care 2008, 31(Supplement 2): S155-S160.

21. Stensvold I, Tverdal A, Urdal P, Graff-Iversen S: Non-fasting serum triglyceride concentration and mortality from coronary heart disease and any cause in middle aged Norwegian women. BMJ 1993, 307(6915):1318-1322.

22. Tverdal A, Foss OP, Leren P, Holme I, Lund-Larsen PG, Bjartveit K: Serum Triglycerides as an Independent Risk Factor for Death from Coronary Heart Disease in Middle-aged Norwegian Men. Am J Epidemio/ 1989, 129(3):458-465.

23. Stampfer MJ, Krauss RM, Ma J, Blanche PJ, Holl LG, Sacks FM, Hennekens CH: A prospective study of triglyceride level, low-density lipoprotein particle diameter, and risk of myocardial infarction. JAMA 1996, 276(11):882-888

24. Nordestgaard BG, Benn M, Schnohr P, Tybjaerg-Hansen A: Nonfasting triglycerides and risk of myocardial infarction, ischemic heart disease, and death in men and women. JAMA 2007, 298(3):299-308.

25. Freiberg JJ, Tybjaerg-Hansen A, Jensen JS, Nordestgaard BG: Nonfasting Triglycerides and Risk of Ischemic Stroke in the General Population. JAMA 2008, 300(18):2142-2152.

26. Eberly LE, Stamler J, Neaton JD: Relation of Triglyceride Levels, Fasting and Nonfasting, to Fatal and Nonfatal Coronary Heart Disease. Arch Intern Med 2003, 163(9):1077-1083.

27. Bansal S, Buring JE, Rifai N, Mora S, Sacks FM, Ridker PM: Fasting compared with nonfasting triglycerides and risk of cardiovascular events in women. JAMA 2007, 298(3):309-316.

28. Adiels M, Olofsson SO, Taskinen MR, Boren J: Overproduction of very lowdensity lipoproteins is the hallmark of the dyslipidemia in the metabolic syndrome. Arterioscler Thromb Vasc Biol 2008, 28(7):1225-1236.

29. Proctor SD, Vine DF, Mamo JC: Arterial permeability and efflux of apolipoprotein B-containing lipoproteins assessed by in situ perfusion and three-dimensional quantitative confocal microscopy. Arterioscler Thromb Vasc Biol 2004, 24(11):2162-2167.

30. Haratz D, Stein O, Shwartz R, Berry EM, Stein Y: Preferential metabolism by macrophages of conditioned rabbit hypercholesterolemic remnant lipoproteins. Biochim Biophys Acta 1988, 959(2):127-133.

31. Elsegood CL, Pal S, Roach PD, Mamo JC: Binding and uptake of chylomicron remnants by primary and THP-1 human monocyte-derived macrophages: determination of binding proteins. Clin Sci (Lond) 2001, 101(2):111-119.

32. Speidel MT, Booyse FM, Abrams A, Moore MA, Chung BH: Lipolyzed hypertriglyceridemic serum and triglyceride-rich lipoprotein cause lipid accumulation in and are cytotoxic to cultured human endothelial cells. High density lipoproteins inhibit this cytotoxicity. Thromb Res 1990, 58(3):251-264.

33. Domoto K, Taniguchi T, Takaishi H, Takahashi T, Fujioka Y, Takahashi A, Ishikawa Y, Yokoyama M: Chylomicron remnants induce monocyte chemoattractant protein-1 expression via p38 MAPK activation in vascular smooth muscle cells. Atherosclerosis 2003, 171(2):193-200.

34. Lamon-Fava S, Herrington DM, Reboussin DM, Sherman M, Horvath KV, Cupples LA, White C, Demissie S, Schaefer EJ, Asztalos BF: Plasma Levels of HDL Subpopulations and Remnant Lipoproteins Predict the Extent of Angiographically-Defined Coronary Artery Disease in Postmenopausal Women. Arterioscler Thromb Vasc Biol 2008, 28(3):575-579.

35. Karpe F, Steiner G, Uffelman K, Olivecrona T, Hamsten A: Postprandial lipoproteins and progression of coronary atherosclerosis. Atherosclerosis 1994, 106(1):83-97

36. Nakamura $T$, Takano $H$, Umetani $K$, Kawabata $K$, Obata JE, Kitta $Y$, Kodama $Y$, Mende A, Ichigi Y, Fujioka D, et al: Remnant lipoproteinemia is a risk factor for endothelial vasomotor dysfunction and coronary artery disease in metabolic syndrome. Atherosclerosis 2005, 181(2):321-327.

37. Nakajima K, Nakano T, Moon HD, Nagamine T, Stanhope KL, Havel PJ, Warnick GR: The correlation between TG vs remnant lipoproteins in the fasting and postprandial plasma of 23 volunteers. Clin Chim Acta 2009, 404(2):124-127.

38. Ginsberg HN, Le NA, Goldberg IJ, Gibson JC, Rubinstein A, Wang-Iverson P Norum R, Brown WV: Apolipoprotein B metabolism in subjects with deficiency of apolipoproteins CIII and Al. Evidence that apolipoprotein CIII inhibits catabolism of triglyceride-rich lipoproteins by lipoprotein lipase in vivo. J Clin Invest 1986, 78(5):1287-1295.

39. Zheng C, Khoo C, Ikewaki K, Sacks FM: Rapid turnover of apolipoprotein C-IIl-containing triglyceride-rich lipoproteins contributing to the formation of LDL subfractions. Journal of Lipid Research 2007, 48(5):1190-1203.

40. Kawakami A, Osaka M, Aikawa M, Uematsu S, Akira S, Libby P, Shimokado K, Sacks FM, Yoshida M: Toll-like receptor 2 mediates apolipoprotein CIIIinduced monocyte activation. Circ Res 2008, 103(12):1402-1409.

41. Sacks FM, Alaupovic P, Moye LA, Cole TG, Sussex B, Stampfer MJ, Pfeffer MA, Braunwald E: VLDL, apolipoproteins B, CIII, and E, and risk of recurrent coronary events in the Cholesterol and Recurrent Events (CARE) trial. Circulation 2000, 102(16):1886-1892.

42. Pilz S, Scharnagl H, Tiran B, Seelhorst U, Wellnitz B, Boehm BO, Schaefer JR, Marz W: Free Fatty Acids Are Independently Associated with All-Cause and Cardiovascular Mortality in Subjects with Coronary Artery Disease. J Clin Endocrinol Metab 2006, 91(7):2542-2547.

43. Pirro $M$, Mauriège $P$, Tchernof $A$, Cantin $B$, Dagenais $G R$, Després JP, Lamarche B: Plasma free fatty acid levels and the risk of ischemic heart disease in men: prospective results from the Québec Cardiovascular Study. Atherosclerosis 2002, 160(2):377-384.

44. Oliver MF: Prevention of ventricular fibrillation during acute myocardial ischemia: control of free fatty acids. J Cardiovasc Pharmacol Ther 2001, 6(3):213-217

45. Tripathy D, Mohanty P, Dhindsa S, Syed T, Ghanim H, Aljada A, Dandona P: Elevation of Free Fatty Acids Induces Inflammation and Impairs Vascular Reactivity in Healthy Subjects. Diabetes 2003, 52(12):2882-2887.

46. Gosmanov AR, Smiley DD, Robalino G, Siquiera J, Khan B, Le NA, Patel RS, Quyyumi AA, Peng L, Kitabchi AE, et al: Effects of oral and intravenous fat load on blood pressure, endothelial function, sympathetic activity, and oxidative stress in obese healthy subjects. Am J Physiol Endocrinol Metab 2010, 299(6):E953-958. 
47. Steinberg HO, Tarshoby M, Monestel R, Hook G, Cronin J, Johnson A, Bayazeed B, Baron AD: Elevated circulating free fatty acid levels impair endothelium-dependent vasodilation. J Clin Invest 1997, 100(5):1230-1239.

48. Schwartz EA, Zhang WY, Karnik SK, Borwege S, Anand VR, Laine PS, Su Y, Reaven PD: Nutrient Modification of the Innate Immune Response: A Novel Mechanism by Which Saturated Fatty Acids Greatly Amplify Monocyte Inflammation. Arterioscler Thromb Vasc Biol 2010, 30(4):802-808

49. Feletou M, Vanhoutte PM: Endothelium-derived hyperpolarizing factor: where are we now? Arterioscler Thromb Vasc Biol 2006, 26(6):1215-1225.

50. Nishimura Y, Usui H, Kurahashi K, Suzuki A: Endothelium-dependent contraction induced by acetylcholine in isolated rat renal arteries. Eur J Pharmacol 1995, 275(2):217-221.

51. Suwaidi JA, Hamasaki S, Higano ST, Nishimura RA, Holmes DR Jr, Lerman A: Long-term follow-up of patients with mild coronary artery disease and endothelial dysfunction. Circulation 2000, 101(9):948-954.

52. Halcox JP, Schenke WH, Zalos G, Mincemoyer R, Prasad A, Waclawiw MA, Nour KR, Quyyumi AA: Prognostic value of coronary vascular endothelial dysfunction. Circulation 2002, 106(6):653-658.

53. Goodfellow J, Ramsey MW, Luddington LA, Jones CJ, Coates PA, Dunstan F, Lewis MJ, Owens DR, Henderson AH: Endothelium and inelastic arteries: an early marker of vascular dysfunction in non-insulin dependent diabetes. BMJ 1996, 312(7033):744-745.

54. Steinberg HO, Chaker H, Leaming R, Johnson A, Brechtel G, Baron AD: Obesity/insulin resistance is associated with endothelial dysfunction. Implications for the syndrome of insulin resistance. J Clin Invest 1996, 97(11):2601-2610.

55. Vogel RA, Corretti MC, Plotnick GD: Effect of a single high-fat meal on endothelial function in healthy subjects. Am J Cardiol 1997, 79(3):350-354.

56. Ceriello A, Taboga C, Tonutti L, Quagliaro L, Piconi L, Bais B, Da Ros R, Motz E: Evidence for an independent and cumulative effect of postprandial hypertriglyceridemia and hyperglycemia on endothelial dysfunction and oxidative stress generation: effects of short- and longterm simvastatin treatment. Circulation 2002, 106(10):1211-1218.

57. Kawano H, Motoyama T, Hirashima O, Hirai N, Miyao Y, Sakamoto T, Kugiyama K, Ogawa $H$, Yasue $H$ : Hyperglycemia rapidly suppresses flowmediated endothelium-dependent vasodilation of brachial artery. J Am Coll Cardiol 1999, 34(1):146-154.

58. Bae JH, Bassenge E, Lee HJ, Park KR, Park CG, Park KY, Lee MS, Schwemmer M: Impact of postprandial hypertriglyceridemia on vascular responses in patients with coronary artery disease: effects of ACE inhibitors and fibrates. Atherosclerosis 2001, 158(1):165-171.

59. Anderson TJ, Uehata A, Gerhard MD, Meredith IT, Knab S, Delagrange D, Lieberman EH, Ganz P, Creager MA, Yeung AC, et al: Close relation of endothelial function in the human coronary and peripheral circulations. J Am Coll Cardiol 1995, 26(5):1235-1241.

60. Steinberg HO, Bayazeed B, Hook G, Johnson A, Cronin J, Baron AD: Endothelial dysfunction is associated with cholesterol levels in the high normal range in humans. Circulation 1997, 96(10):3287-3293.

61. Celermajer DS, Sorensen KE, Gooch VM, Spiegelhalter DJ, Miller OI, Sullivan ID, Lloyd JK, Deanfield JE: Non-invasive detection of endothelial dysfunction in children and adults at risk of atherosclerosis. Lancet 1992, 340(8828):1111-1115

62. Cosentino F, Luscher TF: Endothelial dysfunction in diabetes mellitus. J Cardiovasc Pharmacol 1998, 32(Suppl 3):S54-61.

63. Halcox JP, Donald AE, Ellins E, Witte DR, Shipley MJ, Brunner EJ, Marmot MG, Deanfield JE: Endothelial function predicts progression of carotid intima-media thickness. Circulation 2009, 119(7):1005-1012.

64. Gokce N, Keaney JF Jr, Hunter LM, Watkins MT, Menzoian JO, Vita JA: Risk stratification for postoperative cardiovascular events via noninvasive assessment of endothelial function: a prospective study. Circulation 2002, 105(13):1567-1572

65. Heitzer T, Schlinzig T, Krohn K, Meinertz T, Munzel T: Endothelial dysfunction, oxidative stress, and risk of cardiovascular events in patients with coronary artery disease. Circulation 2001, 104(22):2673-2678.

66. Yeboah J, Crouse JR, Hsu FC, Burke GL, Herrington DM: Brachial flowmediated dilation predicts incident cardiovascular events in older adults: the Cardiovascular Health Study. Circulation 2007, 115(18):2390-2397.

67. Huang PH, Chen JW, Lu TM, Yu-An Ding P, Lin SJ: Combined use of endothelial function assessed by brachial ultrasound and high-sensitive C-reactive protein in predicting cardiovascular events. Clin Cardiol 2007, 30(3):135-140.
68. Frick $M$, Weidinger $F$ : Endothelial function: a surrogate endpoint in cardiovascular studies? Curr Pharm Des 2007, 13(17):1741-1750.

69. Drucker DJ: The biology of incretin hormones. Cell Metab 2006, 3(3):153-165.

70. Kreymann B, Williams G, Ghatei MA, Bloom SR: Glucagon-like peptide-1 736: a physiological incretin in man. Lancet 1987, 2(8571):1300-1304.

71. Holst JJ, Vilsboll T, Deacon CF: The incretin system and its role in type 2 diabetes mellitus. Mol Cell Endocrinol 2009, 297(1-2):127-136.

72. Nauck MA, Heimesaat MM, Orskov C, Holst JJ, Ebert R, Creutzfeldt W: Preserved incretin activity of glucagon-like peptide 1 [7-36 amide] but not of synthetic human gastric inhibitory polypeptide in patients with type-2 diabetes mellitus. J Clin Invest 1993, 91(1):301-307.

73. Willms B, Werner J, Holst JJ, Orskov C, Creutzfeldt W, Nauck MA: Gastric emptying, glucose responses, and insulin secretion after a liquid test meal: effects of exogenous glucagon-like peptide-1 (GLP-1)-(7-36) amide in type 2 (noninsulin-dependent) diabetic patients. J Clin Endocrinol Metab 1996, 81(1):327-332.

74. Naslund E, Barkeling B, King N, Gutniak M, Blundell JE, Holst JJ, Rossner S, Hellstrom PM: Energy intake and appetite are suppressed by glucagonlike peptide-1 (GLP-1) in obese men. Int J Obes Relat Metab Disord 1999, 23(3):304-311.

75. Flint A, Raben A, Astrup A, Holst JJ: Glucagon-like peptide 1 promotes satiety and suppresses energy intake in humans. The Journal of Clinical Investigation 1998, 101(3):515-520.

76. Qin X, Shen H, Liu M, Yang Q, Zheng S, Sabo M, D'Alessio DA, Tso P: GLP-1 reduces intestinal lymph flow, triglyceride absorption, and apolipoprotein production in rats. Am J Physiol Gastrointest Liver Physiol 2005, 288(5):G943-949.

77. Meier JJ, Gethmann A, Gotze O, Gallwitz B, Holst JJ, Schmidt WE, Nauck MA Glucagon-like peptide 1 abolishes the postprandial rise in triglyceride concentrations and lowers levels of non-esterified fatty acids in humans. Diabetologia 2006, 49(3):452-458.

78. Zander M, Madsbad S, Madsen JL, Holst JJ: Effect of 6-week course of glucagon-like peptide 1 on glycaemic control, insulin sensitivity, and [beta]-cell function in type 2 diabetes: a parallel-group study. The Lancet 2002, 359(9309):824-830.

79. Nauck M, Stockmann F, Ebert R, Creutzfeldt W: Reduced incretin effect in type 2 (non-insulin-dependent) diabetes. Diabetologia 1986, 29(1):46-52.

80. Toft-Nielsen MB, Damholt MB, Madsbad S, Hilsted LM, Hughes TE, Michelsen BK, Holst JJ: Determinants of the impaired secretion of glucagon-like peptide-1 in type 2 diabetic patients. J Clin Endocrinol Metab 2001, 86(8):3717-3723.

81. Rachman J, Barrow BA, Levy JC, Turner RC: Near-normalisation of diurnal glucose concentrations by continuous administration of glucagon-like peptide-1 (GLP-1) in subjects with NIDDM. Diabetologia 1997, 40(2):205-211.

82. Toft-Nielsen MB, Madsbad S, Holst JJ: Continuous subcutaneous infusion of glucagon-like peptide 1 lowers plasma glucose and reduces appetite in type 2 diabetic patients. Diabetes Care 1999, 22(7):1137-1143.

83. Inzucchi SE, McGuire DK: New drugs for the treatment of diabetes: part II: Incretin-based therapy and beyond. Circulation 2008, 117(4):574-584.

84. Richter G, Feddersen O, Wagner U, Barth P, Goke R, Goke B: GLP-1 stimulates secretion of macromolecules from airways and relaxes pulmonary artery. Am J Physiol 1993, 265(4 Pt 1):L374-381.

85. Liu H, Hu Y, Simpson RW, Dear AE: Glucagon-like peptide-1 attenuates tumour necrosis factor-alpha-mediated induction of plasmogen activator inhibitor-1 expression. J Endocrinol 2008, 196(1):57-65.

86. Yu M, Moreno C, Hoagland KM, Dahly A, Ditter K, Mistry M, Roman RJ: Antihypertensive effect of glucagon-like peptide 1 in Dahl salt-sensitive rats. J Hypertens 2003, 21(6):1125-1135.

87. Basu A, Charkoudian N, Schrage W, Rizza RA, Basu R, Joyner MJ: Beneficial effects of GLP-1 on endothelial function in humans: dampening by glyburide but not by glimepiride. Am J Physiol Endocrinol Metab 2007, 293(5):E1289-1295.

88. Nystrom T, Gutniak MK, Zhang Q, Zhang F, Holst JJ, Ahren B, Sjoholm A: Effects of glucagon-like peptide-1 on endothelial function in type 2 diabetes patients with stable coronary artery disease. Am J Physiol Endocrinol Metab 2004, 287(6):E1209-1215.

89. Ceriello A, Esposito K, Testa R, Bonfigli AR, Marra M, Giugliano D: The Possible Protective Role of Glucagon-Like Peptide 1 on Endothelium 
During the Meal and Evidence for an "Endothelial Resistance" to Glucagon-Like Peptide 1 in Diabetes. Diabetes Care 2011, 34(3):697-702.

90. Bose AK, Mocanu MM, Carr RD, Brand CL, Yellon DM: Glucagon-like Peptide 1 Can Directly Protect the Heart Against Ischemia/Reperfusion Injury. Diabetes 2005, 54(1):146-151.

91. Liu Q, Anderson C, Broyde A, Polizzi C, Fernandez R, Baron A, Parkes DG: Glucagon-like peptide-1 and the exenatide analogue AC3174 improve cardiac function, cardiac remodeling, and survival in rats with chronic heart failure. Cardiovasc Diabetol 2010, 9:76.

92. Read PA, Khan FZ, Dutka DP: Cardioprotection against ischaemia induced by dobutamine stress using glucagon-like peptide- 1 in patients with coronary artery disease. Heart

93. Kieffer TJ, Mclntosh CH, Pederson RA: Degradation of glucose-dependent insulinotropic polypeptide and truncated glucagon-like peptide 1 in vitro and in vivo by dipeptidyl peptidase IV. Endocrinology 1995, 136(8):3585-3596.

94. Blase E, Taylor K, Gao HY, Wintle M, Fineman M: Pharmacokinetics of an oral drug (acetaminophen) administered at various times in relation to subcutaneous injection of exenatide (exendin-4) in healthy subjects. J Clin Pharmacol 2005, 45(5):570-577.

95. Edwards CM, Stanley SA, Davis R, Brynes AE, Frost GS, Seal LJ, Ghatei MA, Bloom SR: Exendin-4 reduces fasting and postprandial glucose and decreases energy intake in healthy volunteers. Am J Physiol Endocrinol Metab 2001, 281(1):E155-161.

96. Egan JM, Clocquet AR, Elahi D: The insulinotropic effect of acute exendin4 administered to humans: comparison of nondiabetic state to type 2 diabetes. J Clin Endocrinol Metab 2002, 87(3):1282-1290.

97. Kolterman OG, Buse JB, Fineman MS, Gaines E, Heintz S, Bicsak TA, Taylor K, Kim D, Aisporna M, Wang Y, et al: Synthetic exendin-4 (exenatide) significantly reduces postprandial and fasting plasma glucose in subjects with type 2 diabetes. J Clin Endocrinol Metab 2003, 88(7):3082-3089

98. Cervera A, Wajcberg E, Sriwijitkamol A, Fernandez M, Zuo P, Triplitt C, Musi N, DeFronzo RA, Cersosimo E: Mechanism of action of exenatide to reduce postprandial hyperglycemia in type 2 diabetes. Am J Physiol Endocrinol Metab 2008, 294(5):E846-852.

99. Schwartz SL, Ratner RE, Kim DD, Qu Y, Fechner LL, Lenox SM, Holcombe JH: Effect of exenatide on 24-hour blood glucose profile compared with placebo in patients with type 2 diabetes: a randomized, double-blind, two-arm, parallel-group, placebo-controlled, 2-week study. Clin Ther 2008, 30(5):858-867.

100. DeFronzo RA, Okerson T, Viswanathan P, Guan X, Holcombe JH, MacConell L: Effects of exenatide versus sitagliptin on postprandial glucose, insulin and glucagon secretion, gastric emptying, and caloric intake: a randomized, cross-over study. Curr Med Res Opin 2008, 24(10):2943-2952.

101. Klonoff DC, Buse JB, Nielsen LL, Guan X, Bowlus CL, Holcombe JH, Wintle ME, Maggs DG: Exenatide effects on diabetes, obesity, cardiovascular risk factors and hepatic biomarkers in patients with type 2 diabetes treated for at least 3 years. Curr Med Res Opin 2008, 24(1):275-286.

102. Arakawa M, Mita T, Azuma K, Ebato C, Goto H, Nomiyama T, Fujitani Y, Hirose $\mathrm{T}$, Kawamori $\mathrm{R}$, Watada $\mathrm{H}$ : Inhibition of monocyte adhesion to endothelial cells and attenuation of atherosclerotic lesion by a glucagon-like peptide-1 receptor agonist, exendin-4. Diabetes 2010, 59(4):1030-1037.

103. Schwartz EA, Koska J, Mullin MP, Syoufi I, Schwenke DC, Reaven PD: Exenatide suppresses postprandial elevations in lipids and lipoproteins in individuals with impaired glucose tolerance and recent onset type 2 diabetes mellitus. Atherosclerosis 2010, 212(1):217-222.

104. Koska J, Schwartz EA, Mullin MP, Schwenke DC, Reaven PD: Improvement of postprandial endothelial function after a single dose of exenatide in individuals with impaired glucose tolerance and recent-onset type 2 diabetes. Diabetes Care 2010, 33(5):1028-1030.

105. Vella A, Bock G, Giesler PD, Burton DB, Serra DB, Saylan ML, Dunning BE, Foley JE, Rizza RA, Camilleri M: Effects of Dipeptidyl Peptidase-4 Inhibition on Gastrointestinal Function, Meal Appearance, and Glucose Metabolism in Type 2 Diabetes. Diabetes 2007, 56(5):1475-1480.

106. Salehi M, Vahl TP, D'Alessio DA: Regulation of islet hormone release and gastric emptying by endogenous glucagon-like peptide 1 after glucose ingestion. J Clin Endocrinol Metab 2008, 93(12):4909-4916.
107. Matikainen N, Manttari S, Schweizer A, Ulvestad A, Mills D, Dunning BE, Foley JE, Taskinen MR: Vildagliptin therapy reduces postprandial intestinal triglyceride-rich lipoprotein particles in patients with type 2 diabetes. Diabetologia 2006, 49(9):2049-2057.

108. Hsieh J, Longuet C, Baker C, Qin B, Federico L, Drucker D, Adeli K: The glucagon-like peptide 1 receptor is essential for postprandial lipoprotein synthesis and secretion in hamsters and mice. Diabetologia 2010, 53(3):552-561

109. Gaede P, Vedel P, Larsen N, Jensen GVH, Parving HH, Pedersen O: Multifactorial Intervention and Cardiovascular Disease in Patients with Type 2 Diabetes. The New England Journal of Medicine 2003, 348(5):383-393.

110. Bergenstal RM, Wysham C, MacConell L, Malloy J, Walsh B, Yan P, Wilhelm K, Malone J, Porter LE: Efficacy and safety of exenatide once weekly versus sitagliptin or pioglitazone as an adjunct to metformin for treatment of type 2 diabetes (DURATION-2): a randomised trial. The Lancet 2010, 376(9739):431-439.

111. Buse JB, Rosenstock J, Sesti G, Schmidt WE, Montanya E, Brett JH, Zychma M, Blonde L: Liraglutide once a day versus exenatide twice a day for type 2 diabetes: a 26-week randomised, parallel-group, multinational, open-label trial (LEAD-6). The Lancet 2009, 374(9683):39-47.

112. Diamant M, Van Gaal L, Stranks S, Northrup J, Cao D, Taylor K, Trautmann M: Once weekly exenatide compared with insulin glargine titrated to target in patients with type 2 diabetes (DURATION-3): an open-label randomised trial. The Lancet 2010, 375(9733):2234-2243.

113. Pratley RE, Nauck M, Bailey T, Montanya E, Cuddihy R, Filetti S, Thomsen AB, Søndergaard RE, Davies M: Liraglutide versus sitagliptin for patients with type 2 diabetes who did not have adequate glycaemic control with metformin: a 26-week, randomised, parallel-group, open-label trial. The Lancet 2010, 375(9724):1447-1456.

114. Ratner R, Han J, Nicewarner D, Yushmanova I, Hoogwerf BJ, Shen L: Cardiovascular safety of exenatide BID: an integrated analysis from controlled clinical trials in participants with type 2 diabetes. Cardiovasc Diabetol 2011, 10:22.

115. Williams-Herman D, Engel SS, Round E, Johnson J, Golm GT, Guo H, Musser BJ, Davies MJ, Kaufman KD, Goldstein BJ: Safety and tolerability of sitagliptin in clinical studies: a pooled analysis of data from 10,246 patients with type 2 diabetes. BMC Endocr Disord 2010, 10:7.

116. Bloomgarden ZT: Glycemic Control in Diabetes: A Tale of Three Studies. Diabetes Care 2008, 31(9):1913-1919.

117. Best JH, Hoogwerf BJ, Herman WH, Pelletier EM, Smith DB, Wenten M Hussein MA: Risk of Cardiovascular Disease Events in Patients With Type 2 Diabetes Prescribed the Glucagon-Like Peptide 1 (GLP-1) Receptor Agonist Exenatide Twice Daily or Other Glucose-Lowering Therapies. Diabetes Care 2011, 34(1):90-95.

118. Peskin BR, Shcheprov AV, Boye KS, Bruce S, Maggs DG, Gaebler JA: Cardiovascular outcomes associated with a new once-weekly GLP-1 receptor agonist versus traditional therapies for type 2 diabetes: A simulation analysis. Diabetes Obes Metab.

doi:10.1186/1475-2840-10-61

Cite this article as: Ansar et al:: Postprandial hyperlipidemia, endothelial dysfunction and cardiovascular risk: focus on incretins. Cardiovascular Diabetology 2011 10:61

\section{Submit your next manuscript to BioMed Central and take full advantage of:}

- Convenient online submission

- Thorough peer review

- No space constraints or color figure charges

- Immediate publication on acceptance

- Inclusion in PubMed, CAS, Scopus and Google Scholar

- Research which is freely available for redistribution 